\title{
Martyrdom of al-Hallaj and Unity of the Existence: the Condemners and the Commenders
}

\author{
YUSRI MOHAMAD RAMLI ${ }^{1}$
}

\begin{abstract}
Wahdat al-wujud is a very most polemical topic discussed in the world of Islamic Tasawwuf or Sufism since $2^{\text {nd }}$ century of Islamic history. This issue continued to be debated from time to time until today. Wahdat al-wujud or Oneness of the Absolute Existent had made conflict between Muslim scholars. Some scholars become the supporters of this theory and some against this idea. One of the important figures related to this term was al-Hallaj. Al-Husayn ibn Mansur al-Hallajwas a controversial writer and teacher of Islamic mysticism. He is famous for his martyrdom for heresy at the hands of the Abbasid rulers which arousing admiration in some and repression on the others. The drama of his life and death has been considered a reference point in the history of Sufism.
\end{abstract}

Keywords: al-Hallaj, Sufism, Tasawwuf, wahdat al-wujud

His name is Abu al-Mughith al-Husayn bin Mansur al-Hallaj al-Baydawi al-Wasiti. He was born in Shushtar, Khuzistan province of Persia in 858 AD. At an early age al-Hallaj went to live in the city of Wasit, an important Iraqi centre for textiles, trade and Arab culture. His father had become a Muslim and may have supported the family by carding wool. Therefore, his father was called al-Hallaj (cotton-carder) and then this name continued to be carried by him.

Al-Hallaj was attracted to an ascetic way of life at an early age. Not satisfied with merely having learned the Quran by heart, he was motivated to understand its deeper and inner meanings. During his adolescence (c. 874-894), at a time when Islamic mysticism was in its formative period, he began to withdraw from the world and to seek the company of individuals who were able to instruct him in the Sufi way. His teachers, Sahl al-Tustari, 'Amr ibn 'Uthman alMakki, Abu al-Qasim al-Junayd al-Baghdadi, and Abu al-Hasan al-Nuri, were highly respected among the masters of Sufism. Studying first under Sahl al-Tustari, who lived a quiet and solitary life in the city of Tustar in Khuzistan, al-Hallaj later became a disciple of al-Makki of Basra. During this period he married the daughter of the Sufi Abu Ya'qub al-Aqta'. He concluded his instruction in the mystical way under al-Junayd of Baghdad, a brilliant intellect, under whom alMakki had likewise studied. But al-Hallaj was later rejected by them both.

During the next period of his life (c. 895-910), al-Hallaj undertook extensive travels, preaching, teaching, and writing. He made a pilgrimage to Mecca, where he followed a strict discipline for a year. Returning to such regions as Fars, Khuzistan, and Khorasan, he preached and wrote about the way to an intimate relationship with God. In the course of his journeys he attracted many disciples, some of whom accompanied him on a second pilgrimage to Mecca. Afterward, he returned to his family in Baghdad and then set out by sea for a mission to a territory hitherto not penetrated by Islam at that time: India and Turkistan. Following a third pilgrimage to Mecca, he again returned to Baghdad (c. 908).

The milieu in which al-Hallaj preached and wrote was filled with social, economic, political, and religious tensions: all factors that contributed to his later arrest. His thought and activity had been provocative and had been interpreted in various ways, some of which left him highly suspect in the eyes of civil and religious authorities. The Sufi movement, in general, had

\footnotetext{
${ }^{1}$ Yusri Mohamad Ramli, M.A., Lecturer at Department of Theology and Philosophy, Faculty of Islamic Studies, Universiti Kebangsaan Malaysia, 43600 BANGI, Selangor, Malaysia. Email: yusri_mr@ukm.my.
} 
aroused considerable opposition, and its thought and practice had yet to be coordinated with developments in jurisprudence, theology, and philosophy.

Al-Hallaj's propensity for travel and his willingness to share the profundity of his mystical experiences with all who would listen were considered breaches of discipline by his Sufi masters. His travel for missionary purposes was suggestive of the subversive activity of the Qaramitah, a 9th-century movement with Isma'ili affiliations that was founded by Hamdan Qarmat in Iraq, whose acts of terrorism and whose missionaries were undermining the authority of the central government. Through his wife's family, he was suspected of having connections with the destructive Zanj rebellion in southern Mesopotamia that was carried out by oppressed black slaves inspired and led by outside dissidents. The alleged involvement of alHallaj in an attempt at political and moral reform upon his return to Baghdad was an immediate factor in his arrest, and it did nothing to improve his image in the eyes of the political leaders.

Al-Hallaj has been identified as an 'intoxicated' Sufi in contradistinction to a 'sober' one. The former are those who, in the moment of ecstasy, are so overcome by the presence of the divine that awareness of personal identity is lost and who experience a merging with ultimate reality. In that exalted state, the Sufi is given to using extravagant language. Not long before his arrest al-Hallaj is said to have uttered the statement "Ana al-Haqq" (I am the Truth - i.e. God), which provided cause for the accusation that he had claimed to be divine. Such a statement was highly inappropriate in the view of most Muslims. Furthermore, this was the kind of theosophical (divine wisdom) idea that was associated with the Qarmatians and the supporters of the Zanj slaves. There was no consensus about al-Hallaj, however. The long, drawn-out trial proceedings were marked by indecision.

After his arrest in Sus and a lengthy period of confinement (c. 911-922) in Baghdad, alHallaj was eventually crucified and brutally tortured to death in $26^{\text {th }}$ March 922 AD or 309 Hijra. A large crowd witnessed his execution. Al-Hallaj before put to death said:

\author{
Now stands no more between Truth and me \\ Or reasoned demonstration, \\ Or proof of revelation; \\ Now, brightly blazing full, Truth's lumination \\ Each flickering, lesser light.
}

He is remembered to have endured gruesome torture calmly and courageously and to have uttered words of forgiveness for his accusers. In a sense, the Islamic community (ummah) had put itself on trial, for al-Hallaj left behind revered writings and supporters who courageously affirmed his teachings and his experience. In subsequent Islamic history, therefore, the life and thought of al-Hallaj has been a subject seldom ignored.

\title{
His Martyrdom and Oneness of the Existence
}

He wanted to testify of this relationship to God to others, even at the price of his own life, thus even asking his fellow Muslims to kill him and accepting his martyrdom, saying that "what is important for the ecstatic is for the One to reduce him to oneness" (Massignon 1982: 79, 87). He also referred to the martyrdom of Christ, saying he also wanted to die in the supreme confession of the cross (Oliver Clément n.d.: 41). Like Christ, he gave his martyrdom a redemptive significance, believing as he did that his martyrdom was uniting his beloved God and His community of Muslims against himself and thereby bore witness in extremist to the tawhid (the oneness) of both. For his desire of oneness with God, many Muslims criticized him as a 'cryptoChristian' for distorting the monotheistic revelation in a Christian way (Mason 1995: 25).

His death is described by Farid al-Din 'Attar (1994) as a heroic act, as when they are taking him to court, a Sufi asks him: "What is love?". He answers: "You will see it today, tomorrow, and the day after tomorrow." They killed him that day, burned him the next day and threw his ashes to the wind the day after that. "This is love," 'Attar says. His legs were cut off, he smiled and said, "I used to walk the earth with these legs, now there's only one step to heaven, 
cut that if you can." And when his hands were cut off he paints his face with his own blood, when asked why, he says: "I have lost a lot of blood, and I know my face has turned yellow, I don't want to look pale-faced (as of fear)...". We can also acknowledge of al-Hallaj's idea of wahdat alwujud from his sayings:

Ana al-Haqq (I am the Truth). (This is the saying which apparently earned al-Hallaj his martyrdom - al-Haqq also means God)

You know and are not known; you see and are not seen. (Akhbar al-Hallaj: 44)

Your Spirit mixed with my Spirit little by little, by turns, through reunions and abandons. And now I am Yourself, Your existence is my own, and it is also my will. (Diwan al-Hallaj)

I find it strange that the divine whole can be borne by my little human part,

Yet due to my little part's burden, the earth cannot sustain me. (Akhbar al-Hallaj: 11)

I have seen my Lord with the eye of my heart, and I said: "Who are You?" He said:"You." (Diwan al-Hallaj: 10)

I do not cease swimming in the seas of love, rising with the wave, then descending; now the wave sustains me, and then I sink beneath it; love bears me away where there is no longer any shore. (Diwan al-Hallaj: 34)

For most Muslims especially legalistic, tawhid or the unity of God meant that God was inaccessible to man. Al-Hallaj believed that it was only God who could pronounce the tawhid. Love means to stand next to the Beloved, renouncing oneself entirely and transforming oneself in accordance to Him.

Wahdat al-Wujud or the Unity of Being is a philosophy emphasizing that there is no true existence except the Ultimate Truth (God) or in other phrasing that the only truth within the universe is God, and that all things exist within God only. All of his creations emerge from 'adim (non-existence) to wujud (existence) out of his thought only. Hence the existence of God is the only truth (Haqq), and the concept of a separate created universe is a fallacy (Batil).

\section{Views of scholars on Wahdat al-Wujud}

To continue our discussion on this topic, we can generally classify scholars and sects to four groups: who agree and support wahdat al-wujud, who against this idea, who understand its meaning, and who understand it literally.

\section{Group Who Understand and Agree}

For this kind of group, we can specifically divide into three groups. The first group is who are on the same track of al-Hallaj, which mean they were also thought, said, and taught the same ideas. They were famous and always related to the idea of wahdat al-wujud. They are sometime called as a group of philosophical Sufism or Tasawwuf fail-safe. The first group was Abu Yazid alBistami, Ibn Farid, Ibn 'Arabi, Jalal al-Din Rumi, Shaykh Siti Jenar, Hamzah Fansuri, Shams al-Din al-Sumaterani and many others who were inspired by al-Hallaj or inspired him. Here is a poem where Rumi talks about al-Hallaj (Barks 2004):

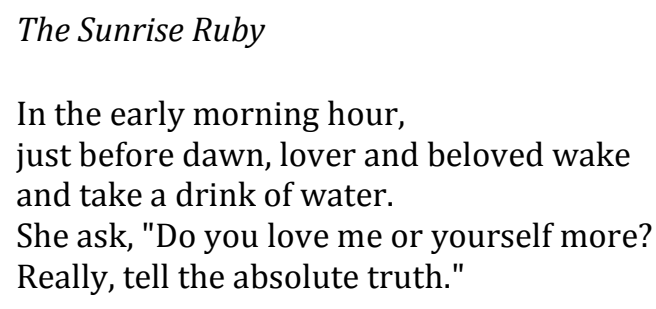


He says, "There's nothing left of me.

I'm like a ruby held up to the sunrise.

Is it still a stone, or a world

made of redness? It has no resistance

to sunlight."

This is how Hallaj said, I am God,

and told the truth!

The ruby and the sunrise are one.

Be courageous and discipline yourself.

Completely become hearing and ear,

and wear this sun-ruby as an earring.

Work. Keep digging your well.

Don't think about getting off from work.

Water is there somewhere.

Submit to a daily practice.

Your loyalty to that

is a ring on the door.

Keep knocking, and the joy inside

will eventually open a window

and look out to see who's there.

The second group is who agreed and supported his idea but not commonly related to the idea of wahdat al-wujud. They are the defender of this idea. Many of them consider him as one of the Saints or Awliya of Allah. They are such as Ibn Khafif who visited him in jail, al-Shibli who is his student, Abu al-Qasim al-Nasir Abadi, al-Qushayri, Ibn 'Ata Allah, Ibn al-Hajj, Ibn 'Aqil who wrote Juz' fi nasr karamat al-Hallaj (Opuscule in Praise of al-Hallaj's gifts), Ibn Qudama, alTufi, Ibn al-Mulaqqin, al-Munawi, al-Sha'rani, 'Abd al-Halim Mahmud, etc.

Abd al-Halim Mahmud (1964: 269) tried to explain about wahdat al-wujud in his commentary of al-Munqidh min al-dalal by al-Ghazali. Wahdat al-wujud (oneness of the absolute existence that is the God Almighty) according to him is different to wahdat al-mawjud (oneness of the creations). Mawjud or creation is various including heaven, earth, mountains, oceans, trees, humans, and many more. There is nobody from Sufis who said about wahdat al-mawjud. A believer cannot say or think such a thing. Moreover, claiming that the Sufis who are the highest eminent among believers to say there is wahdat al-mawjud is truly something absurd.

The thought of wahdat al-mawjud came from the ancient Greek philosophers which had been followed by later philosophers. They said that the God Almighty and all the creatures are the one existence or the same existence. One of them is Heraclitus in ancient Greece who said that God is day and night, winter and summer, many and little, solid and liquid. We could also find the same thing in the modern world like Shelly who said that God is the sweet smile on the lips of cute babies, wind that blow during the sunset, and the star that shine in the dark of night (cAbd al-Halim Mahmud 1964: 269-270). But some think that wahdat al-wujud and wahdat almawjud is the same thing. The supporters of this propaganda continued time to time. When the Sufis talk about al-wujud al-wahid (one existent), their opponents explain al-wujud al-wahid as wahdat al-mawjud although this two things are totally different one to another ('Abd al-Halim Mahmud 1964: 270).

Another thing which became the factor of the confusion about this term according to Abd al-Halim Mahmud (1964: 270) is what had been said by al-Ash ari (r.a.) in his philosophy of Kalam that al-wujud is ayn al-mawjud. But many Sufis, Muslim thinkers, and philosophers rejected this idea. This philosophical idea according to Abd al-Halim Mahmud may be right (in the context of theological Kalam) or may be wrong (in the context of Metaphysical Sufism), just like an other scholar's idea on this matter.

When the Sufis said about al-wujud al-wahid, their oppositions elaborate their thought based on this al-Ashari's opinion whithout looking at Sufis views which then lead them to interpret the saying of Sufis about al-wujud al-wahid (one existent) as al-mawjud al-wahid (one creations). Their idea confused many people from time to time. This thing according to Abd al- 
Halim Mahmud is just the small matter and only about the problem of the term. But ignorance and confusion had made this thing become a polemic and made some people go astray ( $\mathrm{Abd}$ alHalim Mahmud 1964: 270).

The oppositions of Sufism related this idea to al-Hallaj, Ibn 'Arabi, Ibn Farid, and many others which actually did not said by them in any of their books. The only thing they said is alwujud al-wahid. So what is the problem with the one existence? This is the idea what had been brought by the Prophets and the Messengers that is the oneness of God or monotheism (Abd alHalim Mahmud 1964: 271).

Sufis is the people who drown in the divine ocean, across His sea, and breathe His air. There are the people who thank to God for all of His gifts and then God give them His bless and guide them to the straight path, so they can feel and express the oneness of God in their faith, talk, attitude, and action. All of this is based on the word that there is no god but Allah. Their sayings have very deep meaning and they said that Allah is the cause of existence for all existence. He who gives strength to walk to human so they can walk and (Abd al-Halim Mahmud 1964: 273,275).

So why al-Hallaj had been crucified? `Abd al-Halim Mahmud explained that this incident is truly happen as al-Hallaj is a big figure on this field. Like many other Sufis and Sunnis, alHallaj love Ahl al-Bayt (family and a descendant of Prophet Muhammad s.a.w.). At that time, the group of Ahl al-Bayt want to make their own state and they rebelled to the government. Therefore the Abbasid rulers looked the attitude of al-Hallaj towards Ahl al-Bayt as a threat to their kingdom. As al-Hallaj was a great and popular figure in that time, so Abbasid rulers always kept their eyes on him until a conspiracy was made to eliminate him. Therefore Abd al-Halim Mahmud said that the death of al-Hallaj was not because of the problem of religion, but the problem of politics. The people who criticized Sufis like al-Hallaj, Ibn Arabi, Ibn Farid, and many others are the people who have little knowledge about tasawwuf. Because of their ignorance, they interpreted the sayings of Sufis as heretic. This same thing is like what had been said by abed al-Wahhab al-Sha rani as mosquito who want to blow a hill (Abd al-Halim Mahmud 1964: 276277).

The third group is who agreed with the idea of wahdat al-wujud but they try to avoid this thing on their teachings. They tried to avoid conflict between the supporters and oppositions of this theory. They were 'Abd Allah bin 'Alawi al-Haddad, Sayyid Muhammad bin 'Alawi al-Maliki, and many others. They advised people to avoid discussing about wahdat al-wujud and get involved in the debate of this idea because only the eminent scholars and sufis who can say such thing. This is to avoid from confusion and conflict in their path to God.

\section{Group Who Understand and Against al-Hallaj}

Among other Sufis, al-Hallaj regarded as an anomaly. They rejected the idea of wahdat al-wujud as it is contradicted and against the Islamic belief and laws in its literal meaning and can made people go astray. The idea of wahdat al-wujud can only be taught among experts and highest eminent Sufis and scholars. This group includes al-Junayd al-Baghdadi and 'Amr bin 'Uthman alMakki, who was al-Hallaj teachers, al-Nawawi, Ibn Salah, and many others.

Many Sufi masters and teachers felt that it was inappropriate to share mysticism with the masses, yet al-Hallaj openly did so in his writings and through his teachings. He began to make enemies, and the rulers saw him as a threat. This was exacerbated by times when he would fall into trances which he attributed to being in the presence of God. During one of these trances, he would utter Ana al-Haqq meaning "Truth is me" or "I am God" and also, "In my turban is wrapped nothing but God," which was taken to mean that he was claiming to be God, as Al-Haqq is one of the Ninety Nine Names of Allah. In another statement, al-Hallaj would point to his cloak and say, "Ma fi jubbati illa-Allah" meaning "There is nothing inside/underneath my cloak except God."

Al-Hallaj said something people at the time found offensive and could not understand. These utterances led him to a long trial, and subsequent imprisonment for eleven years in a 
Baghdad prison. In the end, he was tortured and publicly crucified (in some accounts he was beheaded and his hands and feet were cut off) by the Abbasid rulers for what they deemed theological error threatening the security of the state. Some Sufis, such as Ahmad Sirhindi, has criticized wahdat al-wujud. Ahmad Sirhindi wrote about the sayings that the universe has no existence of its own and is a shadow of the existence of the necessary being. He also wrote that one should discern the existence of the universe from the Absolute and that the Absolute does not exist because of existence but because of His essence.

Ahmad Sirhindi was one of the main proponents of wahdat al-shuhud. It has often been translated into English as Apparentism. In Arabic it literally means "unity of witness". According to his doctrine, any experience of unity between God and the created world is purely subjective and occurs only in the mind of the believer; it has no objective counterpart in the real world. The former position, Shaykh Ahmad felt, led to pantheism, which was contrary to the tenets of Sunnite Islam. He held that God and creation are not identical; rather, the latter is a shadow or reflection of the Divines Name and Attributes when they are reflected in the mirrors of their opposite non-beings. Abu Hafs Umar al-Suhrawardi and Abd-al-Karim Jili were also proponents of apparentism.

Shah Waliullah made the first attempt to reconcile the two (apparently) contradictory doctrines of wahdat al-wujud (unity of being) of Ibn 'Arabi and wahdat al-shuhud (unity in conscience) of Shaykh Ahmad Sirhindi. Shah Waliullah neatly resolved the conflict, calling these differences 'verbal controversies' which have come about because of ambiguous language. If we leave, he says, all the metaphors and similes used for the expression of ideas aside, the apparently opposite views of the two metaphysicians will agree. The positive result of Shah Wali Allah's reconciliatory efforts was twofold: it brought about harmony between the two opposing groups of metaphysicians, and it also legitimized the doctrine of wahdat al-wujud among the mutakallimun (theologians), who previously had not been ready to accept it.

In his books Lamahat and Sata'at, he discusses the stages of being, the perceptive faculty, the relation of the abstract with the universe, the universal soul and the souls of man, after death, essence, miracles, the scope of man, the soul of the perfect, universal order, source of manifestation, and the transformation of mystics from quality to quality. He also demonstrated that the long-standing assumption that Sufi doctrine was divided between Apparentism and Unity of Being was a difference of expression alone, the latter doctrine being seen as merely a less-advanced stage of projection.

\section{Group Who Just Understand Literally and Against}

This group is mostly who against not even wahdat al-wujud but also the Sufism itself. Among them are some Islamic Jurists, Muhammad bin Abd al-Wahhab, and his followers who are known as Wahhabiyah or Salafiyah. They interpret the meaning of wahdat al-wujud as the unity of God and human or creation which sound against the Islamic belief and the law of sharia. The word of al-Hallaj, "I am the Truth" or to claim as God is clearly for them a heretic word which cannot be said by a Muslim. Some Salafis also criticize the concept of wahdat al-wujud on the grounds that it was a product of Arab interaction with Hindu philosophy, and is not a purely Islamic concept.

\section{Group Who Just Understand Literally and Agree}

They are some who claim to be the follower of the path of Sufis, but their beliefs and acts did not show the same. They interpret the term of wahdat al-wujud (unity of God) as wahdat al-mawjud (unity of creations) which made them go astray. They like to explain about this theory with adding some ideas from greek philosophy and other religions and beliefs which lead them to the concept of pantheism or al-ittihad (unity of God and creations) and al-hulul (manifestation of God in human body) which is against Islamic belief. Moreover, they claimed that they got this 
idea from Sufis like al-Bistami, al-Hallaj, Ibn 'Arabi, and many others. Most of them are from the Batiniyyah sect which is rejected by the majority Muslims in the world.

The doctrine of wahdat al-wujud asserts that everything that exists can only exist because it is an aspect of Divine Reality, hence an aspect of Divine Unity itself. However, Sufi scholars assert that although wahdat al-wujud may be interpreted that Sufism sees the face of God everywhere, it does not mean that it has reduced God to everything. God remains supremely transcendent (tanzih), even though everything which arises and exists resembles him (tashbih). He resembles nothing but himself. However, wahdat al-wujud still being discussed and debated to date and we can still find many people in many kinds of group whether they agree or against; understand its deeper meanings or just its literal.

\section{Acknowledgement}

This work is supported by the Fundamental Research Grant Scheme, Ministry of Higher Education Malaysia [Grant number: FRGS/1/2011/SSI/UKM/03/10].

\section{References}

`Abd al-Qadir `Isa. 1993/1414H. Haqa'iq `an al-Tasawwuf. 5th Edition. Syria: Maktabah Dar al'Irfan.

'Attar, Farid al-Din. 1994. Tazkirat al-awliya. Trans. Abdul Majid Khatib. 12th Ed. Kota Bharu: Pustaka Aman Press Sdn. Bhd.

Al-Attas, Syed Muhammad Naquib. 1963. Some aspects of Sufism as understood and practised among the Malays. Singapore: Malaysian Sociological Research Institute.

Barks, Coleman. 2004. The Essentials Rumi. New York: HarperCollins.

Browne, Edward G. 2009. A Literary history of Persia. Cambridge: Cambridge University Press.

'Abd al-Halim Mahmud. 1964. Al-Munqidh min al-dalal li Hujjat al-Islam al-Ghazali wa abhath fi al-Tasawwuf. 4th Ed. Cairo: Maktabah al-Anjalu al-Misriyah.

Mason, Herbert W. 1995. Al-Hallaj: mystic and martyr of Islam. Richmond, Surrey: Curzon Press.

Massignon, Louis. 1982. The Passion of al-Hallaj: mystic and martyr of Islam. New Jersey: Princeton University Press. . 2001. Diwan al-Hallaj. Indonesia: Putra Langit.

Oliver Clément. n.d. Dio è carita. n.p. n.pb.

Al-Qushayri, `Abd al-Karim. 1991/1412H. Al-Risalat al-Qushayriyyah fi `ilm al-Tasawwuf. Beirut: Dar al-Khayr.

Al-Sa'i al-Baghdadi, 'Ali. 1991. Akhbar al-Hallaj. Damascus: Dar al-Tali'ah al-Jadidah.

Al-Taftazāni, Abu al-Wafa. 1976. Al-Madkhal ila al-Tasawwufal-Islami. Cairo: Dar al-Thaqafah. 